\title{
Nursing practices for pain management in hospitals of a city of Santa Catarina*
}

\author{
Práticas de enfermagem no manuseio da dor em hospitais de um município de Santa Catarina
}

Anna Geny Batalha Kipel ${ }^{1}$, Selma Cristina Franco'1, Luciane Aparecida Muller²

${ }^{*}$ Received from the University of the Joinville Region, Joinville, SC, Brazil.

DOI 10.5935/1806-0013.20150040

\section{ABSTRACT}

BACKGROUND AND OBJECTIVES: Pain is the fifth vital sign and requires from health professionals specific skills and knowledge for its management. This study aimed at evaluating nursing practices for pain management in hospitals of a city in Southern Brazil.

METHODS: This was a cross-sectional and quantitative study carried out by means of a structured questionnaire to evaluate professional characteristics and knowledge about pain in a sample of 418 professionals: 63 nurses and 355 nursing technicians from three hospitals, two public and one private, between July 2012 and August 2013. Chi-square and Fisher Exact tests were used to evaluate associations between explanatory variables and groups (professional category, type of hospital and time of professional exercise), with significance level of $5 \%$.

RESULTS: From all participants, $27.5 \%$ have attended specific discipline in their qualification; $30.6 \%$ have attended pain qualification courses; $66.7 \%$ know about pain evaluation methods and 58.6\% use them. Private hospital professionals are more skilled in pain evaluation methods $(\mathrm{p}<0.001)$, as well as more recently graduated professionals $(\mathrm{p}=0.005)$. These methods were more broadly used by nurses $(\mathrm{p}=0.036)$; private hospital professionals $(p<0.001)$ and those more recently graduated $(p<0.001)$. Nurses better understand the concept of transduction $(\mathrm{p}<0.001)$; private hospital professionals follow more pain evaluation protocols $(\mathrm{p}<0.001)$ as well as those more recently graduated $(\mathrm{p}=0.013)$.

CONCLUSION: Health professionals must improve their knowledge in this area so that nursing practices for pain management are adequately followed in hospitals of a city of Santa Catarina. Keywords: Hospitals, Nursing care, Pain management, Practices.

1. Universidade da Região de Joinville, Joinville, SC, Brasil.

2. Instituto Federal de Educaçăo, Ciência e Tecnologia de Santa Catarina, Joinville, SC, Brasil.

Submitted in May 13, 2015

Accepted for publication in July 08, 2015.

Conflict of interests: none - Sponsoring sources: Scientific initiation scholarship for student of the Hospital Management technologist course, Federal Institute of Education, Science and Technology, Santa Catarina (IFSC).

Correspondence to:

Anna Geny Batalha KIpel

Rua Paulo Malschitzki, 10 - Campus Universitário, Zona Industrial

89219-710 Joinville, SC, Brasil.

E-mail: anna@ifsc.edu.br

(C) Sociedade Brasileira para o Estudo da Dor

\section{RESUMO}

JUSTIFICATIVA E OBJETIVOS: A dor é considerada o quinto sinal vital e exige dos profissionais de saúde habilidades e conhecimentos específicos para seu manuseio. $\mathrm{O}$ objetivo deste estudo foi conhecer a prática de enfermagem no manuseio da dor em hospitais de um município no sul do Brasil.

MÉTODOS: Pesquisa transversal quantitativa, realizada com aplicaçáo de um questionário estruturado que avaliou características profissionais e o conhecimento sobre dor em uma amostra de 418 profissionais: 63 enfermeiros e 355 técnicos de enfermagem, em 3 hospitais, dois públicos e um privado, entre julho de 2012 e agosto de 2013. Para avaliar associaçóes entre as variáveis explicativas e os grupos (categoria profissional, tipo de hospital e tempo de exercício profissional) utilizaram-se os testes Qui-quadrado e Exato de Fisher, adotando-se nível de significância de $5 \%$.

RESULTADOS: Dos profissionais, 27,5\% cursaram disciplina específica em sua formação; 30,6\% realizaram curso de capacitação sobre dor; $66,7 \%$ conhecem métodos de avaliação da dor e $58,6 \%$ os utilizam. Os profissionais do hospital privado possuem mais conhecimento sobre métodos de avaliação da dor $(p<0,001)$, e também os profissionais formados mais recentemente $(\mathrm{p}=0,005)$. A utilizaçáo destes métodos foi maior entre os enfermeiros $(\mathrm{p}=0,036)$; profissionais do hospital privado $(\mathrm{p}<0,001)$ e formados há menos tempo $(\mathrm{p}<0,001)$. Os enfermeiros conhecem mais o conceito de transdução $(\mathrm{p}<0,001)$; os profissionais do hospital privado seguem mais os protocolos para avaliar a dor $(\mathrm{p}<0,001)$, e também aqueles formados há menos tempo $(\mathrm{p}=0,013)$.

CONCLUSÁO: Os profissionais da saúde necessitam melhorar o conhecimento nesta área para que as práticas da enfermagem no manuseio da dor ocorram adequadamente em hospitais de um município de Santa Catarina.

Descritores: Cuidados de enfermagem, Hospitais, Manuseio da dor, Prática.

\section{INTRODUCTION}

Pain is body's defense mechanism which may become a primary reason for human distress, due to incapacities and unpleasant psychological, social and economic repercussions which affect quality of life (QL), thus becoming a worldwide public health problem ${ }^{1}$. 
National and international studies show that approximately $80 \%$ of patients look for health services due to pain ${ }^{1}$ which is the primary reason for hospital admissions ${ }^{2}$.

Pain is referred by approximately $60 \%$ of cancer patients ${ }^{3}$ with increasing prevalence as the disease advances ${ }^{4}$. Moderate to severe postoperative pain is referred by $38.9 \%$ of hospitalized patients ${ }^{5}$. However, in postsurgical patients indices are variable, being that in the postoperative period 5 to $80 \%$ of patients develop surgery-related chronic pain (CP), especially after procedures involving nervous injury. The incidence of post-amputation pain varies from 30 to $80 \%$; from 11.5 to $47 \%$ after thoracotomy and inguinal hernia; from 3 to $56 \%$ after cholecystectomies and up to $50 \%$ after breast surgery ${ }^{6}$. When pain becomes chronic, its prevalence in Brazil is 30 to $40 \%$ and is among major causes for absenteeism, medical leaves, low productivity, labor indemnities and pensions for disability ${ }^{1}$. North-American indices suggest that $31 \%$ of the population have $\mathrm{CP}$, leading to total or partial incapacity in $75 \%$ of cases ${ }^{7}$.

Due to its high prevalence worldwide, pain is currently considered the fifth vital sign and requires from health professionals specific skills and knowledge for its evaluation and management. However, the difficulty of teams to perceive its extension is still a critical point for its control ${ }^{8}$. The lack of specific knowledge of professionals about pain evaluation methods/scales, the unawareness of the implementation of the fifth vital sign and, consequently, the inadequacy of pain handling may contribute to unnecessary suffering and decreased QL of acute and chronic pain patients. So, understanding pain manifestations, clinical pain investigation, selection of effective pain evaluation methods and adequate to patients' needs are critical to minimize pain prevalence and to provide patients' relief.

Considering the critical role of nursing professionals in pain evaluation and management, this study aimed at evaluating nursing practice in evaluating and managing pain in hospitals of a city in Southern Brazil.

\section{METHODS}

This was a cross-sectional study among nursing professionals working in three general hospitals, two public and one private, from the city of Joinville, SC, from 2011 to 2013. For data collection, a questionnaire was applied to all nursing professionals working in the admission sectors of orthopedics and traumatology, renal and liver transplantation, heart diseases, medical clinic and general surgical clinic, neurology, infectology, general and neurologic intensive care units (ICU) and hospital first-aid units (FA) aimed at treating adult patients. Data collection tool was a structured questionnaire with 21 closed questions with multiple choices and three open questions about professionals characteristics (category, time of professional experience and type of hospital they worked with by the time of the study), qualification and specific accreditation about pain, knowledge and use of methods for its evaluation, and nursing professionals' practice with regard to pain.
To evaluate knowledge and use of methods, scales and questionnaires for pain evaluation, two closed questions were asked (know, apply) and one open question was asked about the method they applied. Professionals practice was evaluated by means of four direct closed questions and one open question about their view of the meaning of pain.

Approval of hospitals directors was asked and voluntary adhesion of nursing professionals was obtained by means of the signature of the Free and Informed Consent Term (FICT). Exclusion criteria were professionals on vacations, medical leave, license award and gestational leave.

\section{Statistical analysis}

Data were stored in an electronic spreadsheet created by the program MsExcel 2013. Absolute and relative frequencies analysis was used to present sample general characteristics, and to evaluate possible associations between explanatory variables and groups: professional category (nurses, nursing technicians), evaluated hospitals $(\mathrm{H} 1, \mathrm{H} 2, \mathrm{H} 3)$ and time in the profession (less than 1 year; 1 to 5 years; 6 to 10 years; more than 10 years), Chi-square test was used with significance level of 5\%, calculated by the program R 3.1.2 (R Foundation for Statistical Computing, Vienna, Austria. URL http:// www.r-project.org/).

The study was approved by the Research Ethics Committee, Municipal Hospital São José, process 11044.

\section{RESULTS}

All 418 contacted nursing professionals have agreed to participate in the study. From respondents, $84.9 \%$ were nursing technicians, $60.8 \%$ had more than six years of experience and $44.0 \%$ acted in the state hospital, followed by the hospital linked to health plans $(30.4 \%)$ and the municipal hospital (25.6\%).

It was observed that just $27.5 \%(\mathrm{n}=215)$ of professionals had specific discipline in their graduation, and $30.6 \% \quad(n=128)$ had attended pain qualification courses. There has been no association between pain qualification by specific discipline and professional category $(\mathrm{p}=0.139)$ or type of hospital where they acted $(\mathrm{p}=0.799)$. With regard to professional experience, there have been more professionals more recently graduated with specific discipline on pain ( $\mathrm{p}=0.052)$ and, although the difference was not significant, it could point to a trend.

There has also been no association between pain qualification course attendance and professional category $(\mathrm{p}=0.408)$, type of hospital $(\mathrm{p}=0.441)$ or professional experience $(\mathrm{p}=0.104)$ (Table 1).

Higher indices were found with regard to knowledge (66.7\%; $\mathrm{n}=279)$ and the use of methods to evaluate pain $(58.6 \%$; $\mathrm{n}=245$ ). The method identified as A (numeric scale from 1 to 10$)$ was the most frequently mentioned $(20.33 \% ; n=85)$, followed by method B (visual analog scale) with $11.24 \%$ $(\mathrm{n}=47)$.

It was observed that private hospital professionals are more aware of pain evaluation methods $(\mathrm{p}<0.001)$, similarly to 
more recently graduated professionals $(p=0.005)$. As to the use of such methods, this was more frequent among nurses $(\mathrm{p}=0.036)$, among private hospital professionals $(\mathrm{p}<0.001)$ and among those more recently graduated $(p<0.001)$ (Table 2).

With regard to nursing practice on handling pain, $62.9 \%$ $(n=263)$ have answered that it is better not to medicate patients before they are submitted to clinical investigation, and just $11.7 \%(n=49)$ have reported knowing the transduction concept. Comparison between groups and nursing practice in handling pain has shown that nurses are more knowledgeable about the transduction concept $(\mathrm{p}<0.001)$ (Table 3$)$.
Most professionals believe (78.2\%) that patients' history, their culture and life perceptions, interfere with pain sensation, and $64.8 \%(n=271)$ of professionals follow at least one pain evaluation protocol or systematic routine. Comparison among professionals has shown that those working for the private hospital more often follow pain evaluation protocols $(\mathrm{p}<0.001)$, in addition to those more recently graduated $(\mathrm{p}=0.013)$ (Table 4).

When respondents were asked about the meaning of pain, there were different answers being the most frequent $(22.5 \%$; $\mathrm{n}=94$ ) that "pain is an individual sensation of malaise/discomfort".

Table 1. Distribution of interviewed professionals characteristics according to pain qualification and accreditation, Joinville, 2011-2013 ( $n=418$ )

\begin{tabular}{|c|c|c|c|c|c|c|c|c|c|c|}
\hline \multirow[t]{3}{*}{ Characteristics } & \multicolumn{5}{|c|}{ Studied specific discipline } & \multicolumn{5}{|c|}{ Attended qualification course } \\
\hline & \multicolumn{2}{|c|}{ Yes } & \multicolumn{2}{|c|}{ No } & \multirow[t]{2}{*}{$p$ value } & \multicolumn{2}{|c|}{ Yes } & \multicolumn{2}{|c|}{ No } & \multirow[t]{2}{*}{$p$ value* } \\
\hline & $\mathrm{n}$ & $\%$ & $\mathrm{n}$ & $\%$ & & $\mathrm{~N}$ & $\%$ & $\mathrm{n}$ & $\%$ & \\
\hline \multicolumn{11}{|l|}{ Category } \\
\hline Nurse & 12 & 19.0 & 51 & 81.0 & 0.139 & 16 & 25.4 & 47 & 74.6 & 0.408 \\
\hline Nursing technician & 103 & 29.0 & 252 & 71.0 & & 112 & 31.5 & 243 & 68.5 & \\
\hline \multicolumn{11}{|l|}{ Type of hospital } \\
\hline $\mathrm{H} 1$ (municipal) & 27 & 25.2 & 80 & 74.8 & & 28 & 26.2 & 79 & 73.8 & \\
\hline $\mathrm{H} 2$ (state) & 51 & 27.7 & 133 & 72.3 & 0.799 & 57 & 31.0 & 127 & 69.0 & 0.441 \\
\hline H3 (private) & 37 & 29.1 & 90 & 70.9 & 0 & 43 & 33.9 & 84 & 66.1 & \\
\hline \multicolumn{11}{|l|}{ Experience (years) } \\
\hline Less than 1 & 10 & 31.2 & 22 & 68.8 & & 10 & 31.2 & 22 & 68.8 & \\
\hline 1 to 5 & 47 & 35.6 & 85 & 64.4 & 0.052 & 51 & 38.6 & 81 & 61.4 & 0.104 \\
\hline 6 to 10 & 25 & 21.0 & 94 & 79.0 & & 31 & 26.0 & 88 & 74.0 & \\
\hline More than 10 & 33 & 24.4 & 102 & 75.6 & & 36 & 26.7 & 99 & 73.3 & \\
\hline
\end{tabular}

${ }^{*}$ Chi-square test.

Table 2. Distribution of interviewed professionals characteristics according to knowledge and use of pain evaluation methods, Joinville, 2011$2013(n=418)$

\begin{tabular}{|c|c|c|c|c|c|c|c|c|c|c|}
\hline \multirow[t]{3}{*}{ Charcteristics } & \multicolumn{5}{|c|}{ Know some method } & \multicolumn{5}{|c|}{ Use some method } \\
\hline & \multicolumn{2}{|c|}{ Yes } & \multicolumn{2}{|c|}{ No } & \multirow[t]{2}{*}{$p$ value } & \multicolumn{2}{|c|}{ Yes } & \multicolumn{2}{|c|}{ No } & \multirow[t]{2}{*}{$p$ value* } \\
\hline & $\mathrm{n}$ & $\%$ & $\mathrm{n}$ & $\%$ & & $\mathrm{n}$ & $\%$ & $\mathrm{n}$ & $\%$ & \\
\hline Nurse & 48 & 76.2 & 15 & 23.8 & 0.114 & 45 & 71.4 & 18 & 28.6 & 0.036 \\
\hline Nursing technician & 231 & 65.1 & 124 & 34.9 & & 200 & 56.3 & 155 & 43.7 & \\
\hline H2 (state) & 95 & 51.6 & 89 & 48.4 & $<0.001$ & 73 & 39.7 & 111 & 60.3 & $<0.001$ \\
\hline H3 (private) & 122 & 96.1 & 5 & 3.9 & & 119 & 93.7 & 8 & 6.3 & \\
\hline \multicolumn{11}{|l|}{ Experience (years) } \\
\hline Less than 1 & 27 & 84.4 & 5 & 15.6 & & 28 & 87.5 & 4 & 12.5 & \\
\hline
\end{tabular}

${ }^{*}$ Chi-square test. 
Table 3. Distribution of interviewed professionals characteristics according to nursing practices in pain evaluation and handling, Joinville, 2011$2013(n=418)$

\begin{tabular}{|c|c|c|c|c|c|c|c|c|c|c|}
\hline \multirow[t]{3}{*}{ Characteristics } & \multicolumn{5}{|c|}{ Better not medicate } & \multicolumn{5}{|c|}{ Know transduction concept } \\
\hline & \multicolumn{2}{|c|}{ Yes } & \multicolumn{2}{|c|}{ No } & \multirow[t]{2}{*}{$p$ value } & \multicolumn{2}{|c|}{ Yes } & \multicolumn{2}{|c|}{ No } & \multirow[t]{2}{*}{$\mathrm{p}$ value } \\
\hline & $\mathrm{n}$ & $\%$ & $\mathrm{n}$ & $\%$ & & $\mathrm{n}$ & $\%$ & $\mathrm{n}$ & $\%$ & \\
\hline \multicolumn{11}{|l|}{ Category } \\
\hline Nurse & 40 & 63.5 & 23 & 36.5 & 1.00 & 16 & 25.4 & 47 & 74.6 & \\
\hline Nursing technician & 223 & 62.8 & 132 & 37.2 & & 33 & 9.3 & 322 & 90.7 & $<0.001^{\star}$ \\
\hline \multicolumn{11}{|l|}{ Type of hospital } \\
\hline $\mathrm{H} 1$ (municipal) & 63 & 58.9 & 44 & 41.1 & & 8 & 7.5 & 99 & 92.5 & \\
\hline $\mathrm{H} 2$ (state) & 118 & 64.1 & 66 & 35.9 & 0.603 & 26 & 14.1 & 158 & 85.9 & $0.235^{\star *}$ \\
\hline H3 (private) & 82 & 64.6 & 45 & 35.4 & & 15 & 11.8 & 112 & 88.2 & \\
\hline \multicolumn{11}{|l|}{ Experience (years) } \\
\hline Less than 1 & 24 & 75.0 & 8 & 25.0 & & 6 & 18.8 & 26 & 81.2 & \\
\hline 1 to 5 & 87 & 65.9 & 45 & 34.1 & 0.211 & 15 & 11.4 & 117 & 88.6 & \\
\hline 6 to 10 & 75 & 63.0 & 44 & 37.0 & & 15 & 12.6 & 104 & 87.4 & $0.521^{*}$ \\
\hline More than 10 & 77 & 57.0 & 58 & 43.0 & & 13 & 9.6 & 122 & 90.4 & \\
\hline
\end{tabular}

${ }^{\star}$ Fisher Exact test; ${ }^{* *}$ Chi-square test.

Table 4. Distribution of interviewed professionals characteristics according to nursing practices to evaluate and manage pain, Joinville, 2011$2013(n=418)$

\begin{tabular}{|c|c|c|c|c|c|c|c|c|c|c|}
\hline \multirow[t]{3}{*}{ Characteristics } & \multicolumn{5}{|c|}{ Patients' history interferes with pain } & \multicolumn{5}{|c|}{ Follow pain evaluation protocol } \\
\hline & \multicolumn{2}{|c|}{ Yes } & \multicolumn{2}{|c|}{ No } & \multirow[t]{2}{*}{$p$ value } & \multicolumn{2}{|c|}{ Yes } & \multicolumn{2}{|c|}{ No } & \multirow[t]{2}{*}{$p$ value* } \\
\hline & $\mathrm{n}$ & $\%$ & $\mathrm{n}$ & $\%$ & & $\mathrm{n}$ & $\%$ & $\mathrm{n}$ & $\%$ & \\
\hline \multicolumn{11}{|l|}{ Category } \\
\hline Nurse & 54 & 85.7 & 9 & 14.3 & & 45 & 71.4 & 18 & 28.6 & 0.295 \\
\hline Nursing technician & 273 & 76.9 & 82 & 23.1 & 0.163 & 226 & 63.7 & 129 & 36.3 & \\
\hline \multicolumn{11}{|l|}{ Type of hospital } \\
\hline H1 (municipal) & 83 & 77.6 & 24 & 22.4 & & 62 & 57.9 & 45 & 42.1 & $<0.001$ \\
\hline H2 (state) & 142 & 77.2 & 42 & 22.8 & 0.790 & 105 & 57.1 & 79 & 42.9 & \\
\hline H3 (private) & 102 & 80.3 & 25 & 19.7 & & 104 & 81.9 & 23 & 18.1 & \\
\hline \multicolumn{11}{|l|}{ Experience (years) } \\
\hline Less than 1 & 26 & 81.2 & 6 & 18.8 & & 24 & 75.0 & 8 & 25.0 & \\
\hline 1 to 5 & 110 & 83.3 & 22 & 16.7 & 0.246 & 95 & 72.0 & 37 & 28.0 & 0.013 \\
\hline 6 to 10 & 92 & 77.3 & 27 & 22.7 & & 64 & 53.8 & 55 & 46.2 & \\
\hline More than 10 & 99 & 73.3 & 36 & 26.7 & & 88 & 65.2 & 47 & 34.8 & \\
\hline
\end{tabular}

* Chi-square test.

\section{DISCUSSION}

Our results show a gap in interviewed nursing professionals' qualification with regard to pain. Most had no specific discipline and have not attended qualification courses to acquire competences to adequately manage patients under their care with acute or chronic pain. This result is supported by the opinion of authors who recognize the poor knowledge of professionals to face the challenge of controlling acute and chronic pain requiring aggressive and specialized management ${ }^{9}$.

Nevertheless, most professionals have referred being aware of and knowing how to use pain evaluation methods, which shows that this subject might have been addressed even if in a less emphatic and isolated way by the program content of some disciplines, which is clearly not enough for such prevalent and important symptom from health care viewpoint. We have also observed better qualification of more recently graduated professionals with regard to knowledge and use of pain evaluation methods, which seems to point to a more recent change in these professionals' qualification. Another difference was better qualification of nursing professionals working for the private hospital as compared to two public hospitals, suggesting that these professionals had some qualification in their workplace. Studies have shown, however, the need for professional qualification in this area ${ }^{9,10}$. 
The international academic community discloses its position about pain relief stating that a large number of acute and chronic pains can be relieved and that health professionals need to understand the strategy for their adequate handling ${ }^{11}$. Although stressing the necessary competence of nurses and other professionals in handling pain, studies address the deficiency of the multiprofessional team to relieve it, being this the primary reason for hospitalized patients not receiving adequate management ${ }^{12,13}$. Deficiency in handling pain reinforces the importance of technical qualification courses ${ }^{10,14}$. In a state university of Paraná, studies have shown the need for medical and nursing students to improve their professional qualification, especially with regard to the use of opioid analgesics ${ }^{10,15}$.

Our study has shown a high proportion of nursing professionals inadequately evaluating and managing pain, showing better qualification of the nurse category. It is supposed that pain is addressed in graduation courses, however, not as a primary subject, but rather as a sub-subject inserted in different curricula. Again it was observed a differential in handling pain which points to better practices among professionals acting in the private hospital, as compared to the two public hospitals, and among more recently graduated professionals. We understand the need to deepen comparative studies involving pain management quality in public and private institutions. Studies carried out in public and private institutions, respectively, point to significant indices above $40 \%$ of referred pain of different etiologies and age groups ${ }^{16,17}$, suggesting that pain is a common and highly prevalent event, regardless of the characteristics of the institution and of professionals working for it.

With regard to evaluation process, the use of one and multidimensional scales is critical. In this process, it is important to understand that pain intensity is also related to anxiety and possible meanings it has for patients. In our study, most professionals have reported knowing and applying methods, however there is a gap in the knowledge about its adequate management with analgesics.

So, following a pain evaluation protocol (standardization of specific routines) is critically important for its control, as well as knowing adequate methods for its management. Such actions are in line with ethical principles of assistance ${ }^{18}$.

Authors report that adequate management of painful patients partially depends on nursing team evaluation, because they continuously assist patients, increasing the possibility of noticing pain complaints and promptly using resources to minimize it $^{12,19}$. Understanding and adequately recording pain particularities, such as site, onset, intensity, duration, nature, pattern, periodicity, sensory and affective qualities of patients, improvement/worsening factors, its meaning for patients and their families, interference in daily life activities, in affective relationships and in work, expectations with regard to the disease and its treatment, normal behavior in stress situations, and types and results of previous treatments, will allow the evaluator to understand the presentation and relate it to initial etiology or trauma, aiming at preventing or decreasing possible complications, and also at promoting therapy adjustments when necessary ${ }^{1,20}$. These actions may significantly contribute to improve QL of painful patients.

It is worth mentioning that a limitation of this study was the fact of the data source being a self-referred questionnaire, that is, based on professionals' answers to questions, which may cause some distortion. In addition, it is possible that our results do not portray the reality of other contexts, since it was carried out in hospitals with management characteristics of different people, which could affect some results.

Finally, in light of results, it is necessary to emphasize the importance of institutional and management policies aimed at ongoing education of health professionals, aiming at qualifying offered health care in public and private sectors.

\section{CONCLUSION}

Our study has shown a low percentage of nursing professionals with specific qualification on pain, which is reflected in their knowledge and practice which were considered, in their majority, inadequate for pain evaluation and management. Best results among more recently graduated professionals and among those working for the private hospital show differences which should be more deeply evaluated by future studies.

\section{ACKNOWLEDGMENTS}

Raniere José Ramos Gomes Santos, for statistical support. To IFSC, for scientific initiation incentive for graduation students.

\section{REFERENCES}

1. Bottega FH, Fontana RT. A dor como quinto sinal vital: utilização da escala de avaliaçáo por enfermeiros de um hospital geral. Texto Contexto Enferm. 2010;19(2):283-90.

2. Nascimento LA, Krelling MC. Avaliação da dor como quinto sinal vital: opinião de profissionais de enfermagem. Acta Paul Enferm. 2011;24(1):50-4.

3. Shvartzman P, Friger M, Shani A, Barak Y, Yoram C, Singer Y. Pain control in ambulatory cancer patients--can we do better? J Pain Symptom Manage. 2003;26(2):716-22.

4. Ferreira LL, Cavenaghi S, Marino LH. Recursos eletroterapêuticos no tratamento da dor oncológica. Rev Dor. 2010;11(4):339-42.

5. Gaudard AM, Saconato H. Controle da dor pós-operatória de pacientes submetidos à cirurgia abdominal em dois hospitais públicos de Brasília. Com Ciências Saúde. 2012;23(4):341-52.

6. Sadatsune EJ, Leal PC, Clivatti J, Sakata RK. Dor crônica pós-operatória: fisiopatologia, fatores de risco e prevenção. Rev Dor. 2011;12(1):58-63.

7. Kreling MC, da Cruz DA, Pimenta CA. [Prevalence of chronic pain in adult workers]. Rev Bras Enferm. 2006;59(4):509-13. Portuguese.

8. Barreto RF, Gomes CZ, Silva RM, Signorelli AA, Oliveira LF, Cavellani CL, et al Avaliaçấo de dor e do perfil epidemiológico, de pacientes atendidos no pronto-socorro de um hospital universitário. Rev Dor. 2012;13(3):213-9.

9. Fontes $\mathrm{KB}$, Jaques AE. O papel da enfermagem frente ao monitoramento da dor como o $5^{\circ}$ sinal vital. Cienc Cuid Saúde. 2007;6(Suppl 2):S481-7.

10. Barros SR, Pereira SS, Almeida Neto A. A formação de acadêmicos de enfermagem quanto à percepçấo da dor em duas instituiçốes de ensino superior. Rev Dor. 2011;12(2):131-7.

11. Lynch ME, Watson $\mathrm{CN}$. The pharmacotherapy of chronic pain: a review. Pain Res Manag. 2006;11(1):11-38.

12. Marinangeli F, Narducci C, Ursini ML, Paladini A, Pasqualucci A, Gatti A, et al. Acute pain and availability of analgesia in the prehospital emergency setting in Italy: a problem to be solved. Pain Pract. 2009;9(4):282-8

13. Mota FA, Marcolan JF, Diccini S, Milanez AM. Avaliaçăo da analgesia controlada pelo 
paciente no pós-operatório de cirurgia cardíaca, com infusão contínua de morfina. Rev Dor. 2010;11(4):292-6.

14. Silva BA, Ribeiro FA. Participação da equipe de enfermagem na assistência à dor do paciente queimado. Rev Dor. 2011;12(4):342-8.

15. Sereza TW, Dellaroza MS. O que está sendo aprendido a respeito da dor na UEL? Semina: Cienc Biol Saude. 2003;24(1):55-66.

16. Ponte HJ, Pucci FH, Moreira Filho HF, Teófilo CR, Pires Neto RJ. Avaliação de manifestaçóes dolorosas em pacientes internados em hospital de referência, com diagnóstico provisório de dengue. Rev Dor. 2011;12(2):104-7.
17. Batista AG, Vasconcelos LA. Principais queixas dolorosas em pacientes que procuram clínica de fisioterapia. Rev Dor. 2011;12(2):125-30.

18. Brasil. Constituiçấo da República Federativa do Brasil.[acesso em 2 de março de 2015]. Disponível em: http://www.senado.gov.br/legislacao/const/con1988/ con1988_05.10.1988/con1988.pdf

19. Macedo AC, Romanek FA, Avelar MC. Gerenciamento da dor no pós-operatório de pacientes com câncer pela enfermagem. Rev Dor. 2013;14(2):133-6.

20. Pimenta CA, Koizumi MS, Ferreira MT, Pimentel IL. Avaliaçáo da experiência dolorosa. Rev Bras Med. 1995;74(2):69-75. 